\title{
Oxygen uptake in relation to body weight in a Hill- stream fish Glyptothorax telchitta (Ham.)
}

\author{
Bharat Raj Subba ${ }^{1}$ and Tapan Kumar Ghosh ${ }^{2}$ \\ ${ }^{1}$ Department of Zoology, Post Graduate Campus, T.U., Biratnagar, Nepal \\ ${ }^{2}$ University Department of Zoology, TM Bhagalpur University, Bhagalpur, India \\ E-mail: subbabharat@yahoo.com
}

\begin{abstract}
Oxygen uptake $\left(\mathrm{VO}_{2}\right)$ through the gills of a hill-stream fish Glyptothorax telchitta from the Saptakoshi river (Nepal) has been studied in relation to different body weights. The oxygen uptake was determined at $24.0 \pm 1^{\circ} \mathrm{C}$ using a cylindrical glass respirometer with continuous water flow system. The aquatic oxy gen uptake through the gills increased from 1.048 to $8.115 \mathrm{mlO}_{2} \mathrm{~kg}^{-1} \cdot \mathrm{h}^{-1}$ within the body weight range of 3.215 to $31.355 \mathrm{~g}$. A fish of $17.052 \mathrm{~g}$ average body weight consumes $4.461 \mathrm{mlO}_{2}$ while the weight specific oxy gen uptake was found to be $267.915 \mathrm{mlO}_{2} \mathrm{~kg}^{-1} \cdot \mathrm{h}^{-1}$. The relation between oxy gen uptake $\left(\mathrm{VO}_{2}\right)$ and body weight was determined by performing regression analysis using logarithmic transformation. It has been found that with a unit increase in body weight, the oxy gen uptake per unit time $\left(\mathrm{mlO}_{2} \mathrm{~h}^{-1}\right)$ increases by a power of 0.930 showing significant positive correlation whereas, the weight specific oxygen uptake decreases by a power of 0.070 showing significant but negative correlation.
\end{abstract}

Key words: Hill-stream, Glyptothorax telchitta, body weight, oxy gen uptake.

\section{Introduction}

Oxygen uptake is considered as a measure of energy requirements for metabolism. Generally, with an increase in metabolic activity, the rate of oxygen uptake also increases. Oxy gen uptake in a fish depends on various extrinsic and intrinsic factors viz. temperature, level of dissolved oxygen and carbon dioxide in ambient water, $\mathrm{pH}$, salinity, season, nutrition, sex of fish, level of hormones, body weight (Fry, 1947; Dejours, 1975). Several workers have studied the relationship between oxy gen uptake and body weight in fishes (Pravateshwararao, 1960; Mookerji, 1964; Kamler, 1972; Munshi, 1984; Rooj, 1984; Singh et al., 1991; Farrell et al., 2001; 2003; Bhattacharya \& Subba, 2006).

In the present study an attempt has been made to study the routine oxy gen uptake in a hill-stream fish, Glyptothorax telchitta of different body weight to establish the relationship between the weight and oxy gen uptake.

\section{Materials and Methods}

Live specimens of $G$. telchitta of different weight groups were collected from the Saptakoshi river (at Tribeni of Dhankuta district) and Barahkshetra and maintained in a plastic drum of 250 liter capacity. The plastic drum was connected with a pipe for 
continuous supply of cold water supplied from the stream. At the bottom of the drum, pebbles collected from the river bed were kept to provide a natural condition to the fish. Just above two inches from the bottom of the drum, an outlet with a tap to control the water level was fitted with. The fishes were fed with earthworm and pupae of white ant twice a day. Water of the drum was changed completely once in every 24 hrs. Feeding was stopped at least $24 \mathrm{hrs}$ before experimentation.

The oxygen uptake rate from water was measured in a closed glass respirometer as designed by Munshi and Dube (1973). The flow of water from the reservoir (a plastic drum of 301 capacity) to the respirometer was maintained according to the size of the fish to avoid suffocation and stress. The respirometer was covered with a piece of black cloth leaving a small space with a view to keep the fish stress free and count the opercular frequency. Two sets of water samples were taken i.e., inspired (collected before the respirometer) and the expired i.e., the water coming out of the respiometer (Fig. 1). Oxy gen concentration of inspired and expired water was measured by means of Winkler's volumetric method (Welch, 1948). The difference between the oxygen contents of the inspired and expired water together with the rate of water flow $(\mathrm{ml} / \mathrm{h})$ through the respirometer, were used to calculate the oxy gen up take rate.

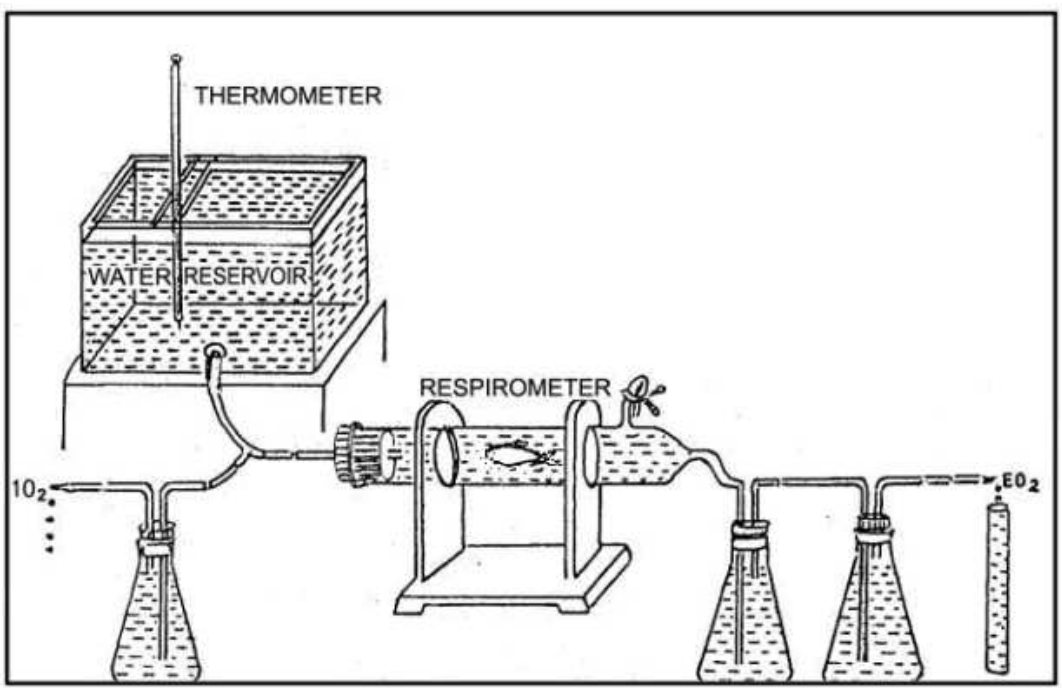

Figure 1. Experiment set up for measurement of aquatic oxygen uptake in Glyptothorax telchitta.

Three to four readings were taken at every half an hour interval for each fish. The experiments were performed at $24.0 \pm 1^{\circ} \mathrm{C}$. Regression analysis using logarithmic transformation was done to show the relation between oxygen uptake and body weight.

\section{Observation and Results}

Glytothorax telchitta a benthic hill-stream fish is a purely water breathing Sisorid. Its gills are respiratory organs for the extraction of oxy gen from water. Measurements of the rate of routine oxygen uptake from the flow-through water in eight (8) weight groups of Glyptothorax telchitta were made and the data is summarized in Table 1. The data were analyzed using logarithmic transformations for the allometric relationship which are in the (Table 2). Computerised data on oxy gen uptake for 1,10 , 50 and $100 \mathrm{~g}$ fish are presented in the Table 3. 
Table 1. Means value of the rate of oxygen uptake $\left(\mathrm{VO}_{2}\right)$ per unit time $\left(\mathrm{mlO}_{2} \cdot \mathrm{h}^{-1}\right)$ in relation to body weight (W) in Glyptothorax telchitta at $24.0 \pm 1.0^{\circ} \mathrm{C}$ temperat ure.

\begin{tabular}{|c|c|c|c|c|}
\hline \multirow{2}{*}{$\begin{array}{c}\text { Body weight } \\
\text { (g) }\end{array}$} & \multirow{2}{*}{$\begin{array}{l}\text { Opercular } \\
\text { frequency }\end{array}$} & \multicolumn{3}{|c|}{ Oxygen uptake $\mathrm{VO}_{2}\left(\mathrm{mlO}_{2} \cdot \mathrm{h}^{-1}\right)$} \\
\hline & & O bse rued value & Estimated value & 95\% Confidence limit \\
\hline $3.215 \pm 0.723$ & $98 \pm 1$ & $1.048 \pm 0.353$ & 0.950 & $\begin{array}{l}1.160 \\
0.780\end{array}$ \\
\hline $5.650 \pm 0.000$ & $88 \pm 0$ & $1.48 \pm 0.000$ & 1.600 & $\begin{array}{l}1.920 \\
1.340\end{array}$ \\
\hline $10.093 \pm 3.192$ & $90 \pm 1$ & $2.608 \pm 0.113$ & 2.750 & $\begin{array}{l}3.260 \\
2.320\end{array}$ \\
\hline $15.190 \pm 1.441$ & $89 \pm 0$ & $3.838 \pm 2.336$ & 4.020 & $\begin{array}{l}4.770 \\
3.400\end{array}$ \\
\hline $19.405 \pm 1.188$ & $87 \pm 2$ & $4.948 \pm 0.184$ & 5.050 & $\begin{array}{l}6.000 \\
4.260\end{array}$ \\
\hline $24.310 \pm 0.000$ & $87 \pm 3$ & $6.517 \pm 0.000$ & 6.230 & $\begin{array}{l}7.420 \\
5.230\end{array}$ \\
\hline $27.200 \pm 1.626$ & $87 \pm 2$ & $7.136 \pm 1.116$ & 6.920 & $\begin{array}{l}8.260 \\
5.800\end{array}$ \\
\hline $31.355 \pm 0.000$ & $85 \pm 0$ & $8.11 \pm 0.000$ & 7.900 & $\begin{array}{l}9.460 \\
6.590\end{array}$ \\
\hline
\end{tabular}

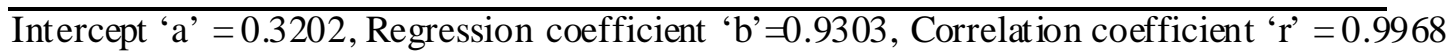

Table 2. intercept ' $a$ ' regression coefficient ' $b$ ' and correlation coefficient ' $r$ ' to show the relationship bet ween oxygen uptake $\mathrm{VO}_{2}\left(\mathrm{mlO}_{2} \cdot \mathrm{h}^{-1}\right)$ and body weight.

\begin{tabular}{ccccc}
\hline Fish & Oxygen uptake & In te rce pt (a) & Slope (b) & Correlation coefficient (r) \\
\hline \multirow{3}{*}{ G. telchitta } & $\mathrm{VO}_{2}\left(\mathrm{mlO}_{2} \cdot \mathrm{h}^{-1}\right)$ & 0.320 & 0.069 & 0.997 \\
& $\mathrm{VO}_{2}\left(\mathrm{mlO}_{2} \cdot \mathrm{g}^{-1} \cdot \mathrm{h}^{-1}\right)$ & 0.320 & -0.069 & 0.683 \\
\hline
\end{tabular}

Table 3. Summary of equations showing the relationship between body weight and oxygen uptake at $24.0 \pm 1.0^{\circ} \mathrm{C}$ temperature.

\begin{tabular}{|c|c|c|}
\hline Parameter & $\mathrm{VO}_{2}$ per unit time $\mathrm{mlO}_{2} \cdot \mathrm{h}^{-1}$ & $\mathrm{VO}_{2} /$ gram body weight $\mathrm{mlO}_{2 \cdot} \mathrm{g}^{-1} \cdot \mathrm{h}^{-1}$ \\
\hline $\begin{array}{l}\text { Body weight vs. } \\
\text { oxygen uptake. }\end{array}$ & $\begin{array}{l}\log \mathrm{VO}_{2}=0.3202+0.9303 \log \mathrm{W} \\
\text { or, } \mathrm{VO}_{2}=0.3202 \mathrm{~W}^{0.9303}\end{array}$ & $\begin{aligned} & \log \mathrm{VO}_{2}=0.3202-0.0697 \log \mathrm{W} \text { or } \\
& \mathrm{VO}_{2}=0.3202 \mathrm{~W}^{0.0697}\end{aligned}$ \\
\hline
\end{tabular}

As soon as the fish was introduced into the cylindrical glass respirometer containing little water, the fish showed erratic movements for a while. When the respirometer was completely filled up with the reservoir water, the fish moved to and fro in search of hiding place. The fish seemed to be under stress. The opercular movement was so high that it could not be counted accurately through eyes; however, the fish gradually became quiet after about 30 to 40 minutes. Then the flow rate of inspired water was so adjusted that the fish did not feel any stress and could move freely within the cy lindrical chamber.

The atmospheric temperature recorded during the experimental time ran ged from $25^{\circ} \mathrm{C}$ to $26^{\circ} \mathrm{C}$ whereas, the temperature of water ranged from $23^{\circ} \mathrm{C}$ to $25^{\circ} \mathrm{C}$, the $\mathrm{pH}$ of water ranged from 6.8 to 7 , similarly the oxy gen content of ambient water ranged from 14.18 to $15.62 \mathrm{mg}^{-1}$. 
Relation ship between body weight and oxygen uptake per unit time $\left(\mathrm{mlO}_{2} \cdot \mathrm{h}^{-1}\right)$ at $24.0 \pm 1^{\circ} \mathrm{C}$.

In Glytothorax telchitta, the oxygen uptake gradually increased from 1.048 to 8.115 $\mathrm{mlO}_{2} \cdot \mathrm{h}^{-1}$ with increase in body weight from $3.315 \mathrm{~g}$ to $31.355 \mathrm{~g}$. A fish of $19.026 \mathrm{~g}$ average body weight consumed $4.344 \mathrm{mlO}_{2} \cdot \mathrm{h}^{-1}$. A straight line was obtained when these data were plotted on a graph

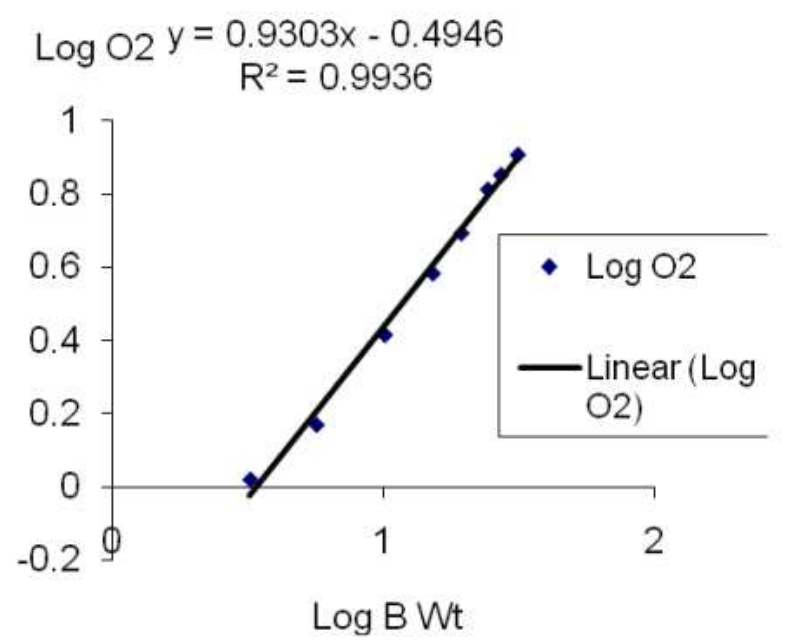

Figure 2. $\mathrm{Log} / \log$ plots showing the relationship between body weight and oxygen uptake $\left(\mathrm{m} 1 \mathrm{O}_{2} \cdot \mathrm{h}^{-1}\right)$ at $24.0 \pm 1^{\circ} \mathrm{C}$ in G. telchitta.

The expression of the relationship between the two variables has been made by the following allometric equation.

$\mathrm{VO}_{2}={ }_{\mathrm{a}} \mathrm{W}^{\mathrm{b}}$ (Where, $\mathrm{VO}_{2}=\mathrm{O} x y$ gen uptake per unit time, $\mathrm{a}=$ intercept or value for $1 \mathrm{~g}$ fish, $b=$ slope of regression line and $\mathrm{W}=$ body weight)

The log of the oxy gen uptake $\left(\mathrm{mlO}_{2} \cdot \mathrm{h}^{-1}\right)$ in relation to body weight gave a straight line, when different scores were fitted by the least squares regression method (Fig. 2). The slope (b) of the regression line was 0.9303. The estimated value of oxy gen uptake for $1 \mathrm{~g}$ fish and the correlation co-efficient ' $\mathrm{r}$ ' between oxygen uptake and body weight were 0.3202 and $0.9968(\mathrm{p}<0.001)$ respectively. The latter value indicates a high degree of correlation. The relationship between oxy gen uptake per unit time $\left(\mathrm{mlO}_{2} \cdot \mathrm{h}^{-1}\right)$ and body weight (Table 2) may be represented by the following equation.

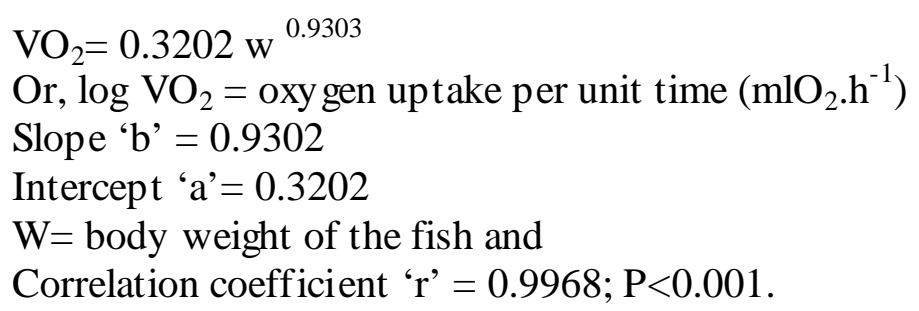

Summary of the equations are in the Table 3.

The computed values for the rate of oxy gen uptake for a fish weight 1, 10, 50 and 100 $\mathrm{g}$ body weight were $0.3202,2.7275,12.180$ and $23.2319\left(\mathrm{mlO}_{2} \cdot \mathrm{h}^{-1}\right)$ respectively (Table 4). 
Table 4. Statistically estimated dat a for oxy gen uptake $\left(\mathrm{VO}_{2}\right)$ at temperat ure $240 . \pm 1.0^{\circ} \mathrm{C}$ for 1 , 10,50 and $100 \mathrm{~g}$ fishes based upon regression analysis using least square method. Their $95 \%$ confidence limits are also given.

\begin{tabular}{ccccc}
\hline $\begin{array}{c}\text { Body weight } \\
(\mathbf{g})\end{array}$ & $\begin{array}{c}\text { Oxygen uptake } \\
\mathbf{m l O}_{\mathbf{2}} \mathbf{h}^{\mathbf{- 1}}\end{array}$ & $\begin{array}{c}\text { 95\% confidence } \\
\text { Limit }\end{array}$ & $\begin{array}{c}\text { Oxygen uptake } \\
\mathbf{m l O}_{\mathbf{2}} \mathbf{g}^{-1} \mathbf{h}^{\mathbf{- 1}}\end{array}$ & $\begin{array}{c}\text { 95\% confidence } \\
\text { limit }\end{array}$ \\
\hline 1.00 & 0.0320 & 0.392 & 0.0320 & 0.0392 \\
& & 0.262 & & 0.262 \\
10.00 & 2.728 & 3.963 & 0.0273 & 0.0296 \\
& & 1.877 & & 0.188 \\
50.00 & 12.189 & 8.963 & 0.420 & 0.399 \\
& & 7.440 & & 0.149 \\
1000.00 & 23.232 & 40.078 & 0.232 & 0.401 \\
& & 13.467 & & 0.135 \\
\hline
\end{tabular}

Relationship between body weight and oxygen uptake per unit body weight $\left(\mathrm{mlO}_{2 g}{ }^{\mathrm{h}} \mathrm{h}^{-1}\right)$ at $24.0 \pm 1^{\circ} \mathrm{C}$.

The weight specific oxygen uptake $\left(\mathrm{mlO}_{2} \mathrm{~g}^{-1} \cdot \mathrm{h}^{-1}\right)$ decreased with increasing body weight (Table 1). The weight specific oxygen uptake in G. telchitta decreased from 0.326 to $0.258 \mathrm{mlO}_{2} \mathrm{~g}^{-1} \cdot \mathrm{h}^{-1}$ with increase in body weight from $3.22 \mathrm{~g}$ to $31.36 \mathrm{~g}$. The weight specific oxygen uptake of a fish of 19.039 average body weight was found to be $0.26 \mathrm{mlO}_{2} \mathrm{~g}^{-1} \cdot \mathrm{h}^{-1}$

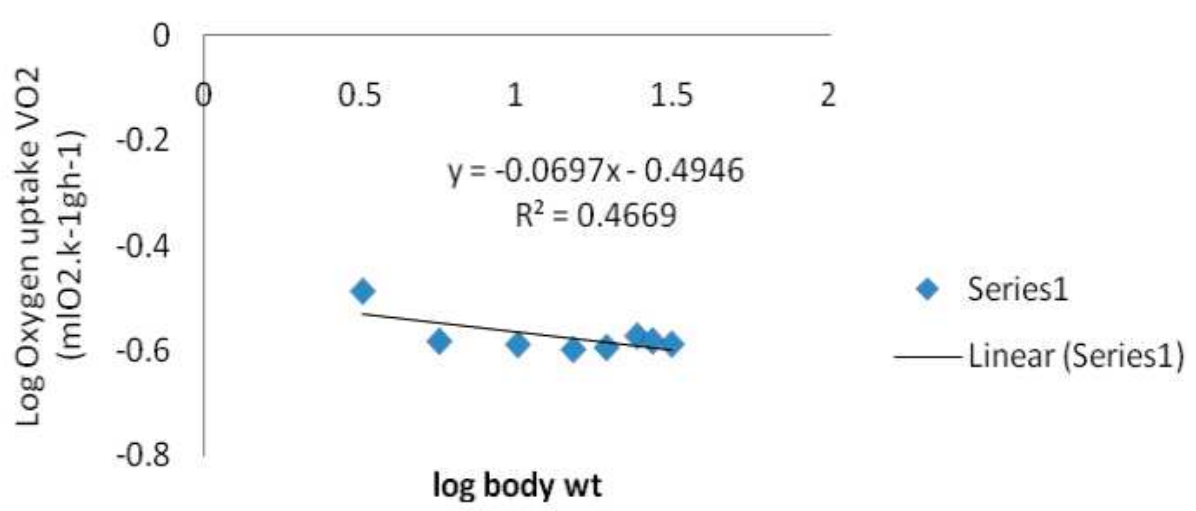

Figure 3. $\log / \log$ plots showing the relationship between body weight and weight specific oxygen uptake $\left(\mathrm{mlO}_{2} \mathrm{~g}^{-1} \cdot \mathrm{h}^{-1}\right)$ at $24.0 \pm 1^{\circ} \mathrm{C}$ in G. telchitta.

A straight line with slope of 0.0698 was obtained when the data for weight specific oxy gen uptake rate were plotted against body weight on log-log coordinates (Fig. 3). The estimated value for a $1 \mathrm{~g}$ fish was 0.3202 . The relationship between the body weight specific oxy gen up take rate has been shown by the following expressions.

$$
\begin{aligned}
& \mathrm{VO}_{2}=0.3202 \mathrm{~W}^{-0.0697} \\
& \text { Or, Log } \mathrm{VO}_{2}=0.3203-0.0697 \log \mathrm{W} .
\end{aligned}
$$

From the above expression; it is evident that the weight specific oxy gen uptake rate decreased with unit increase in body weight by a power of -0.0697 . The correlation coefficient ' $r$ ' was found to be $0.6826(\mathrm{P}<0.2)$ which indicates that the relationship is significant. The estimated value of oxy gen uptake rate $\left(\mathrm{mlO}_{2} \mathrm{~g}^{-1} \cdot \mathrm{h}^{-1}\right)$ for $1,10,50$ and $100 \mathrm{~g}$ fish were $0.3202,0.273$, and 0.232 respectively. 


\section{Discussion}

The rate of oxygen uptake in fish depends upon various abiotic and biotic factors (Imabay ashi and Takahashi, 1987). Of the different biotic factors, body weight plays a very important role and it is well known that a normal increase in oxygen uptake is associated with an increase in body weight. Since the value of exponent ' $b$ ' relating to oxy gen uptake per minute time in most of the fish is less than 1, the weight specific to oxy gen uptake $\left(\mathrm{mlO}_{2} \mathrm{~g}^{-1} \cdot \mathrm{h}^{-1}\right)$ decreases with increase in body weight.

Several workers have suggested different exponent values to state the relationship between oxygen uptake and body weight. Proser and Brown (1961) broadly generalized this value and suggested that it could range from 0.67 to 1.0. However, exception to this range is not uncommon. Exponent value as low as 0.5 was reported by Ruhland (1965) and 0.531 by Munshi and Dube (1973). Similarly, exp onent values of more than 1.0 have also been reported (Wares and Igram, 1979; Munshi et al., 1978). An exponent ' $b$ ' value greater than 1.0 means that it predicts the weight specific oxy gen uptake increase with increasing body weight.

In the present study, the oxygen uptake per unit time in hill-stream Sisorid catfish, Glytothorax telchitta was estimated to be 0.930 . This value is higher than the exponent values reported for a number of purely aquatic breathing fishes (Jager and Dekkers, 1975; Ojha and Singh, 1981; Sinha 1983; Roy and Munshi, 1984; Singh et al., 1991). The slope value of $G$. telchitta was much higher than the ' $b$ ' values of many air breathing fish (Munshi and Dube, 1973; Ojha et al., 1978). But the exponent value 0.841, in the facultative air-breathing Siluroid, Clarias batrachus (Munshi et al., 1976) was comparatively very closer to the exponent value of $G$. telchitta (i.e., 0.9303.).

The exponent value 0.9303 'b' of G. telchitta was very close to 0.960 and 0.976 in Puntius sophore and Crenimugil labrosus repectively (Flowerdew and Grove, 1980). But it was lower than 1.053 in Pimephles promelas (Wares and lgram, 1979).

When the exponent value of G. telchitta was compared with other hill stream fishes, it was found to be a little more than 0.873 that of Garra lamta but less than 1.20 that of Noemacheilus rupicola (Rooj, 1984). The higher exponent value of G. telchitta suggests that the gills of this fish are better developed than most of the fish mentioned above. This slope values may be attributed to their active life in the oxy gen rich water.

The slope values for weight specific oxygen uptake (i.e., $\mathrm{VO}_{2} \mathrm{mlO}_{2} \mathrm{~g}^{-1} \cdot \mathrm{h}^{-1}$ ) was found to be -0.0697 in $G$. telchitta. The computed slope values -0.1259 and 0.1346 in $G$. lamta and $N$. rupicola respectively indicate that the oxygen uptake per unit body weight decreased more rapidly in G. lamta (1.259) than in G. telchitta (0.0697) as the body weight of the fish increased. However, in $N$. rupicola the weight specific oxy gen uptake will continue to increase with increase in body weight by a power function of 0.1346 on the basis of Lipskaya's (1974) definition it may be said that the intensity of metabolism was more in N. rupicola followed by G. lamta and G. telchitta.

The intercept value ' $a$ ' in case of G. telchitta was found to be 0.320 which is higher than the values for many purely aquatic breathing fishes (Ojha and Munshi, 1974; Jager and Dekkers, 1975; Roy and Munshi, 1984; Singh, and Munshi, 1991) but lower than the intercept values for some aquatic breathing fishes. 
For $1 \mathrm{~g}$ fish, the computed value of intercept ' $\mathrm{a}$ ' in case of $G$. telchitta found to be 0.320 which is higher than the values reported for many purely aquatic breathing fishes (Table 5). This is an indication to a higher rate of metabolic decrease with unit increase in body weight in G. telchitta but this intercept value is lower than the values reported for some other purely aquatic breathing fishes (Table 5).

Table 5. Computed data on aquatic oxygen uptake rate $\left(\mathrm{mlO}_{2} \cdot \mathrm{h}^{-1}\right)$ for different fish species of $1 \mathrm{~g}$ body weight for comparison with $G$. telchitta.

\begin{tabular}{lcl}
\hline Fish species & VO $_{2} \mathbf{m l O}_{2} \mathbf{h}^{-1}$ & \multicolumn{1}{c}{ References } \\
\hline Ictalunis nebulosus & 0.084 & Jager \& Dekkers (1975) \\
Clarias batrachus & 0.134 & Munshi et al. (1974) \\
Macrognathus aculeatum & 0.140 & Ojha \& Munshi(1974) \\
Cyprius casrpio & 0.186 & Jager \& Dekkers (1975) \\
Macrognathus auleatum & 0.213 & Ojha \& Munshi (1974) \\
Heteropneustes fossilis & 0.215 & Munshi et al. (1978) \\
Catostomus commersonii & 0.216 & Jager \& Dekkers (1975) \\
Catla catla & 0.263 & Kunwar et al. (1989) \\
Cirrhinus mrigala & 0.251 & Roy \& Munshi(1984) \\
Anguilla annquilla & 0.277 & Iager \& Dekkers (1991) \\
Rita rita & 0.287 & Singh et al. (1991) \\
Glyptothorax relchitta & 0.320 & Subba (1999) \\
Glossogobius giuris & 0.321 & Singh \& Munshi (1985) \\
Channa gachua & 0.394 & Ojha et al. (1978) \\
Salmo trutta & 0.368 & Jager \& Dekkers(1975) \\
Samlo gairdneri & 0.369 & Jager \& Dekkers (1975) \\
Mystus cavasius & 0.532 & Ojha \& Singh (1981) \\
Anabas testudineus & 0.545 & Munshil \& Dube (1973) \\
Nemacheilus mipicola & 0.575 & Rooj (1984) \\
Acipencer stellatus & 0.577 & Jager \& Dekkers (1975) \\
Garra lamta & 0.816 & Rooj (1984) \\
\hline
\end{tabular}

The intercept values 'a' reported for certain air breathing fishes Clarias batrachus (0.134), Heteropnuesters fossilis (0.215) and Anguilla anguilla (0.277) were less than the intercept value of $G$. telchitta but it was found to be higher in Chana gachua (0.394) and Anabus testudineus (0.545) in the same condition.

The oxygen uptake for $1 \mathrm{~g}$ in hill-stream fishes, $N$. rupicola (0.628) and G. lamta (0.813) are two to three times more than the intercept 'a' value for G. telchitta. This suggests that the metabolic rate of $1 \mathrm{~g} N$. rupicola and $G$. lamta are almost two to three times more than that of a $G$. telchitta of similar body weight.

From the studies of oxygen uptake rate of G. telchitta it can be concluded that the rate of oxy gen up take is neither high nor low.

\section{Acknowle dge ment}

One of the authors B.R. Subba is indebted to the University Grants Commission, Nepal for financial assistance during the period of research work.

\section{References}

Dejours, P. 1975. Principles of comparative respiratory physiology. American Elsevier, Amsterdam, New York, Noth Holland. 252 p. 
Farrell, A.P., P.E. Gallaugher \& R. Routledge. 2001. Rapid recovery of exhausted adult coho salmon after commercial capture by troll fishing. Can. J. Fish. Aquat. Sci. 58: 2319-2324.

Farrell, A.P., C.G. Lee, K. Tierney, A. Hodaly, S. Clutterham, M.C. Healey, S.G. Hinch \& A. Lotto. 2003. Field-based measurements of oxy gen uptake and swimming performance with adult Pacific salmon, Oncorhynchus sp. using a mobile respirometer swim tunnel. J. Fish Biol. 62: 64-84.

Flowerdew, M.W. \& D.J. Grove. 1980. An energy budget for juvenile Thick-lipped mullet, Crenimugil laborious (Risso). J. Fish. Biol. 17(4): 395-410.

Fry, F.E.J. 1947. Effect of the environment on animals activity. Univ. Toranto Studies. Biol., Ser. 55, Publ. Ontario Fisheries Res. Lab. 68: 1-62.

Imabay shi, H. \& M. Takahash. 1987. Oxy gen consumption of post larval and juvenile Red sea bream Pagrus major with special reference to group effect. J Fac. Appl. Biol., Sci., Hiroshima Univ. 26: 15-21.

Jager, S.D. \& W.J. Dekkers. 1975. Relationships between gills structure and activity in fish, Neth. J. Zool. 25(3): 276-308.

Kamler, F. 1972. Respiration in carps in relation to body size and temperature. Pol. Arch. Hydrobiol. 19: 325-331.

Kunwar, G.K., A. Pandey \& J.S.D. Munshi. 1989. Oxygen uptake in relation to body weight of two freshwater major carps Catla catla (Ham.) and Labeo rohita (Ham.) Ind. J. Anim. Sci. 59(5): 621-624.

Lipskaya, N.Y. 1974. Metabolic rates in the young of some tropical fish species. J. Ichthyol. 14(6): 934-943.

Munshi, J.S.D \& S.C. Dube. 1973. Oxy gen uptake capacity of gills in relation to body size of air-breathing fish, Anabas testudineus (Bloch). Acta. Physiol. A. Sci. Hungaricae. 44: 113-123.

Munshi, J.S.D., B.N. Pandey, P.K. Pandey \& J. Ojha. 1978. Oxy gen uptake through gills and skin and in relation to body weight of an air-breathing siluroid fish, Saccobranchus (=Heteropneustes) fossilis (Bloch). J. Zool. Lond. 184: 171-180.

Ojha, J. \& R. Singh. 1981. Oxy gen uptake in relation to body weight of the freshwater catfish, Mystius cavasius (Ham.). Ind. J. Exp. Biol. 19(2): 126-129.

Parvatheswararao, V. 1960. Studies on the oxy gen consumption in tropical poikilotherms. IV. Studies on oxy gen consumption in freshwater fish, Puntius sophore (Ham.) in relation to size and temperature. Proc. Natn. Inst. Sci., India. 26:64-72.

Rooj, N.C. 1984. Structure and function of the respiratory organs of certain hill-stream fishes of Chhotanagpur division. University Department of Zoology, Bhagalpur University, Bhagalpur, India. (Ph.D. Thesis)

Roy, P.K. \& J.S.D. Munshi. 1984. Oxygen uptake in relation to body weight and respiratory surface area in Cirrhinus mrigala (Ham.) at two different seasonal temperatures. Proc. Ind. Natn. Sci. Acad. B 50(4): 387-394.

Singh, D.K., O.N. Singh \& J.S.D. Munshi. 1991. Oxygen uptake in relation to body weight in Rita rita (Ham.) (Bagridae, Pices) at two different seasonal temperatures. J. Freshwater Biol. 3(1): 15-21.

Wares, W.D. \& R. Igram. 1979. Oxy gen consumption in the fathead minnow (Pimephales promelas Rafinosque), I. Effects of weight, temperature, group size, oxy gen level and opercular movement rate as a function of temperature. Comp. Biochem. Physiol., 62A: 351-356. 